\title{
MITES OF THE GENUS PROCTOLAELAPS BERLESE, 1923 (ACARI: MESOSTIGMATA: MELICHARIDAE) ASSOCIATED WITH BARK BEETLES IN ASIAN RUSSIA
}

\author{
Viacheslav A. Trach ${ }^{1 *}$ and Alexander A. Khaustov ${ }^{2}$
}

\author{
${ }^{1}$ I.I. Mechnikov Odessa National University, Odessa, Ukraine \\ ${ }^{2}$ Tyumen State University, Tyumen, Russia \\ *corresponding author; e-mail: vatrach@gmail.com
}

\begin{abstract}
Six mite species of the genus Proctolaelaps Berlese, 1923 (Acari: Mesostigmata: Melicharidae) are recorded from bark beetles and in their galleries in Asian Russia. One of them, Proctolaelaps dendroctoni Lindquist and Hunter, 1965, is found for the first time in Palaearctic; its female is redescribed. Proctolaelaps hystricoides Lindquist and Hunter, 1965, P. hystrix (Vitzthum, 1923) and P. scolyti Evans (1958) are recorded for the first time in Russia. A key to females of the genus Proctolaelaps, associated with subcortical beetles, is provided.
\end{abstract}

KEY WORDS: Parasitiformes, Monogynaspida, Ascoidea, Scolytinae, systematics, new species, phoresy.

DOI: 10.21684/0132-8077-2017-25-2-151-163

\section{INTRODUCTION}

The mite family Melicharidae includes 11 genera and more than 200 species (Moraes et al. 2016). Melicharids are known from soil, litter, plants (i.e., their flowers and fruits), rotten wood, stored products, seaweeds, colonies of fruit flies, on cockroaches, beetles, moths, ants, bees, bumblebees and their nests, birds, small mammals and their nests, corps, and excrements (e.g., De Leon 1963; Westerboer 1963; Treat and Niederman 1967; Bregetova 1977; Fain et al. 1977; Karg 1985, 1988a; Hanekom et al. 1988; OConnor et al. 1991; Faraji 2011; Halliday 2001; Mašán et al. 2013; Moraes et. al. 2015, 2016).

Currently, the largest cosmopolitan melicharid genus Proctolaelaps Berlese, 1923 includes about 140 described species (Abo-Shnaf and Moraes 2016; Literakova et al. 2016; Moraes et al. 2016; RuedaRamírez et al. 2016). About 25 species of the genus Proctolaelaps are phoretic on beetles (cossonines, bark beetles, stag beetles, sap beetles, erotylids, scarab beetles, leaf beetles, silphids, and carabid beetles). These mites are especially common on subcortical beetles (Vitzthum 1923; Evans 1958; Samšiňák 1960; Hirschmann 1962, 1972; Costa 1963; Westerboer 1963; Lindquist and Hunter 1965; Ishikawa 1968; Lindquist 1971; Wisniewski 1980; Karg 1988b; Stone 1988; Mašán 1998; Ma et al. 2003; Gwiazdowicz 2007; personal observations).

Thirteen species of the genus Proctolaelaps have been reported from Russia: P. arctorotundus Nikolsky, 1984; P. bickleyi (Bram, 1956); P. bombophilus (Westerboer, 1963); P. cossi (Dugès, 1834); P. fiseri Samšiňák, 1960; P. jueradeus (Schweizer, 1949); $P$. longisetosus (Postner, 1963); P. ornatus (Postner, 1963); P. parvanalis (Thor, 1930); P. pseudofiseri
Nikolsky, 1984; P. pygmaeus (Müller, 1859); P. sibiriensis (Davydova, 1988); P. xyloteri Samšiňák, 1960 (Bregetova 1977; Petrova 1982; Nikolsky 1984; Davydova and Nikolsky 1986; Andreev, 1988; Davydova 1988; Klimov 1998; Marchenko 2002, 2012, 2017; Maslov and Matusevich 2008; Makarova 2009, 2011, 2012; Khaustov et al. 2016).

During the study of mites, associated with bark beetles in Asian Russia (Siberia and the Far East), six species of the genus Proctolaelaps were recorded on bark beetles and in bark beetle galleries. The aims of this paper are the following: to present the new records of phoretic mites of the genus Proctolaelaps; to redescribe (with an extended set of measurements) a female of the poorly known species Proctolaelaps dendroctoni Lindquist and Hunter (1965); and to provide a key to the subcortical beetle-associated Proctolaelaps species.

\section{MATERIAL AND METHODS}

Bark beetles were collected from their galleries using an aspirator, after which they were placed into vials with $96 \%$ ethanol. The beetles, as well the mites obtained from the beetles and their galleries, were examined with the aid of the stereomicroscope Discovery V8 (Carl Zeiss, Germany). Most of the collected mites were mounted in a Hoyer's medium for the purposes of light-microscopy. The morphology of mites was studied with the help of the Axio Imager A2 (Carl Zeiss, Germany) compound microscope with the phasecontrast and the DIC objectives. Mikmed-1 Lomo microscope, equipped with a binocular head AU-12 and an ocular micrometer AM9-2, was also used. 
SEM micrographs were taken with the aid of a JEOL-JSM-6510LV SEM microscope. The morphological terminology generally follows Evans and Till (1979). All pore-like structures, glandular openings (solenostomes), and poroids (lyrifissures) are designated as "pores". Dorsal and ventral setae were labelled according to the systems of Lindquist and Evans (1965), and Lindquist (1994). Palpal and leg chaetotaxy follows Evans (1963a, b, 1969). Lengths of shields were measured from the anterior to posterior shield margins along the midline. The length of the second cheliceral segment was measured from their base to the apex of the fixed digit. The length of legs was taken from the base of the coxa to the apex of the tarsus, excluding the ambulacrum. The measurements are given in micrometers $(\mu \mathrm{m})$. The material is deposited in the Zoological Museum of Tyumen State University (Tyumen, Russia) and in the collections of the Department of Zoology in I.I. Mechnikov Odessa National University (Odessa, Ukraine).

\section{SYSTEMATICS}

\section{Family Melicharidae}

Genus Proctolaelaps Berlese, 1923

Type species: Proctolaelaps productus Berlese, 1923, by monotypy

\section{PROCTOLAELAPS DENDROCTONI LINDQUIST AND HUNTER, 1965}

Figs. 1-2, 3a, 4

Proctolaelaps dendroctoni Lindquist and Hunter, 1965, p. 25, Figs. 20-30.

The type series of $P$. dendroctoni includes specimens from the USA (Georgia, Louisiana and Texas). The mites were found in galleries of bark beetles Dendroctonus frontalis Zimmerman, 1868, Ips avulsus (Eichhoff, 1868), I. calligraphus (Germar, 1824) and on the adult $D$. frontalis (Lindquist and Hunter 1965). Kinn (1983) studied the life cycle of $P$. dendroctoni and quoted Wilson (1980), according to whom this mite species is usually phoretic on beetle associates of scolytids. This observation is especially applicable to the tenebrionid Corticeus glaber (LeConte, 1878) - a facultative predator of bark beetles. We have also recorded the phoresy of this species on Corticeus sp. (Fig. 4). This is a new record for the fauna of the Palearctic.

Diagnosis. Dorsal shield reticulate, smooth only in center of podonotal region. Female with 42 pairs of setae on dorsal shield. Length of setae in
$J$-series does not exceed half distance to base of next posterior seta. Pre-sternal area without platelets. Sternal shield mainly reticulate, smooth posteriorly, pattern of lines in central part primarily transverse. Anus of middle size, located in central part of anal shield. Soft cuticle around of anal shield in female with 13 pairs of setae. Anterior margin of epistome narrowly rounded, denticulate. Deutosternum in female with 6 rows of denticles, rows $1-5$ connected by lateral lines, anterior 4 rows each with 1-3 denticles, $5^{\text {th }}$ row widened, with $3-5$ denticles, $6^{\text {th }}$ row free, widened, with $4-5$ denticles, $7^{\text {th }}$ row absent. Deutosternum in male with 1-2 unconnected denticles in area of $7^{\text {th }}$ row. Corniculi asymmetrical. Fixed cheliceral digit in female with 5-7 teeth, movable digit with 2 teeth. Fixed cheliceral digit in male with 5-7 teeth, movable digit edentate, with only apical tooth. Leg chaetotactic formulae normal for genus, leg segments without macrosetae, some setae on tarsi II-IV thickened.

Redescription. Female ( $\mathrm{n}=6$; Figs. 1, 2, 3a, 4b).

Idiosomal dorsum (Figs. 1a, 4b). Dorsal shield oval; 370-395 long and 218-231 maximum width at $r 5$ level; smooth in central part of podonotal region, other surface reticulate, pattern of lines between setae $J 2$ and $J 4$ primarily transverse; holotrichous, with 42 pairs of setae $(j 1-j 6, z 1-z 6$, $s 1-s 6, r 2-r 6, J 1-J 5, Z 1-Z 5, S 1-S 5, R 1-R 4)$ and 22 pairs of distinguishable pores. Soft cuticle with 2 pairs of setae of $U R$-series and setae $R 5$. All dorsal setae simple, needle-like; measurements of some setae: j1 18-21,j6 12-14, J5 9-10, Z5 32-37, S3 20-21.

Idiosomal venter (Figs. 2a, 3a). Tritosternum with trapezoidal base, 11-12 long, 9-10 wide at base, laciniae pilose, fused for about half of total length (21-24), their free parts 24-29 long. Pre-sternal area transversely lineate, without evident platelets. Sternal shield fused with endopodal platelets of coxae I/II and coxae II/III; 82-86 long along midline, 122-130 wide at level of endopodal platelets of coxae I/II, 120-134 wide at level of endopodal platelets of coxae II/III, 78-82 wide in narrowest place at about mid-level of coxae II; with 3 pairs of setae (st 1-st3; 19-21 long) and 2 pairs of pores (iv1, iv2), pore $i v 1$ positioned posteriad seta st1, pore $i v 2$ positioned between setae st 2 and st 3 ; sternal shield rounded posteriorly; mainly reticulate, but smooth in posterior part, pattern of ornamentation lines in central area primarily transverse (Fig. 3a). Setae $s t 4$ and pores $i v 3$ located on metasternal platelets, length st4 16-18. Epigynal shield reticulate; its anterior margin broadly rounded, overlap- 


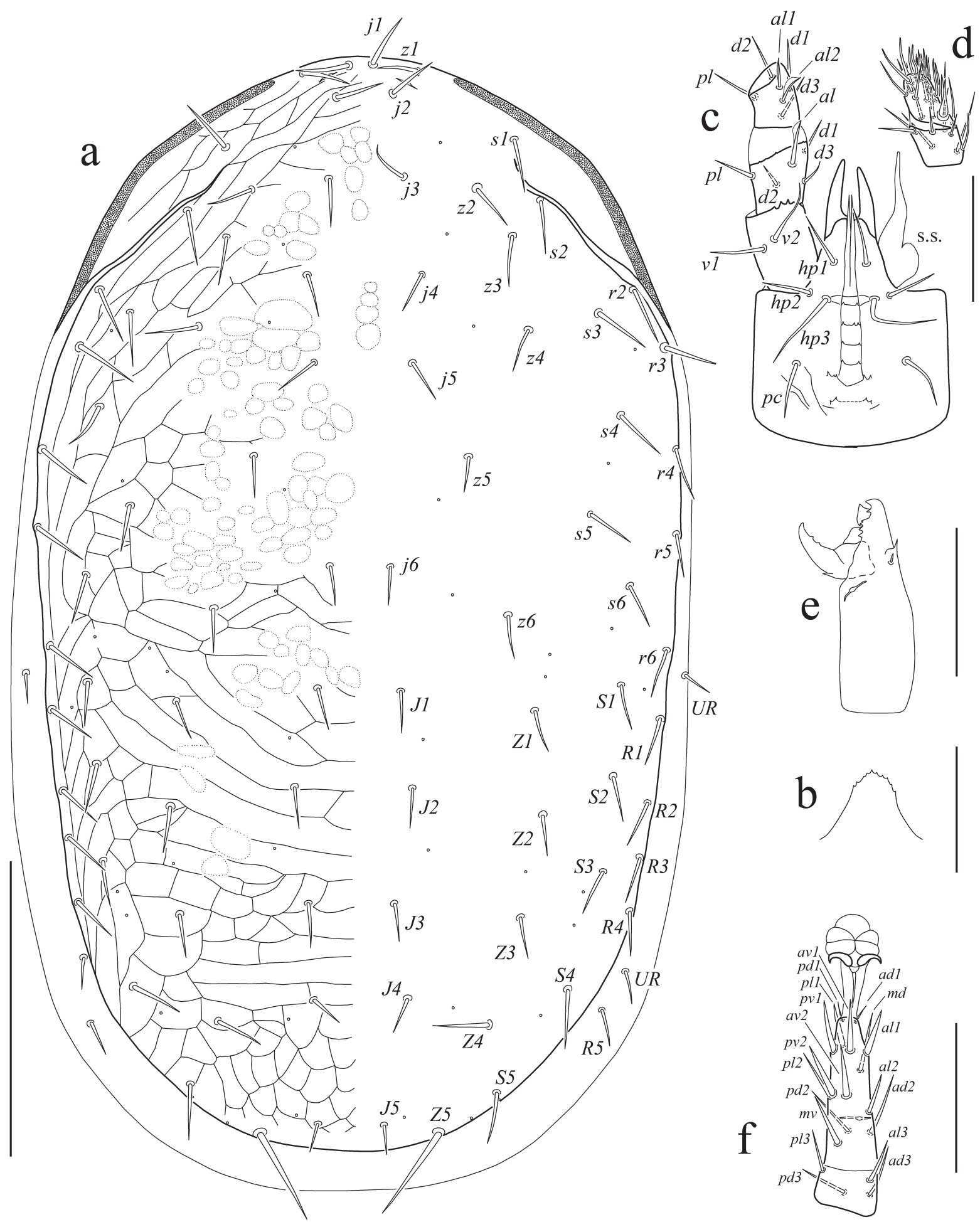

Fig. 1. Proctolaelaps dendroctoni Lindquist and Hunter, 1965, female: a-idiosoma, dorsal view; b-epistome; csubcapitulum and palp (from trochanter to genu), ventral view; d-palptibia and palptarsus, dorsal view; e-chelicera, lateral view; f-tarsus II, ventral view. Scale bars $100 \mu \mathrm{m}$ (a), $50 \mu \mathrm{m}$ (b-f).

ping posterior sternal shield area, widened behind level of st 5 and convex posteriorly; 141-147 long, with greatest width of anterior part 78-80, greatest width of posterior part 71-78; bearing setae st5; length st5 16-17; genital pores placed off the shield. Postgenital platelets absent. Free endopodal plates strongly formed between coxae III and IV. Anal shield oval, with anterior margin rounded, slightly protuberant, posterior margin truncate; $67-71$ long and 55-57 wide; reticulate; anus located in centre of shield, anal opening 21-23 long; cribrum well developed; one pair of pores present; length of 


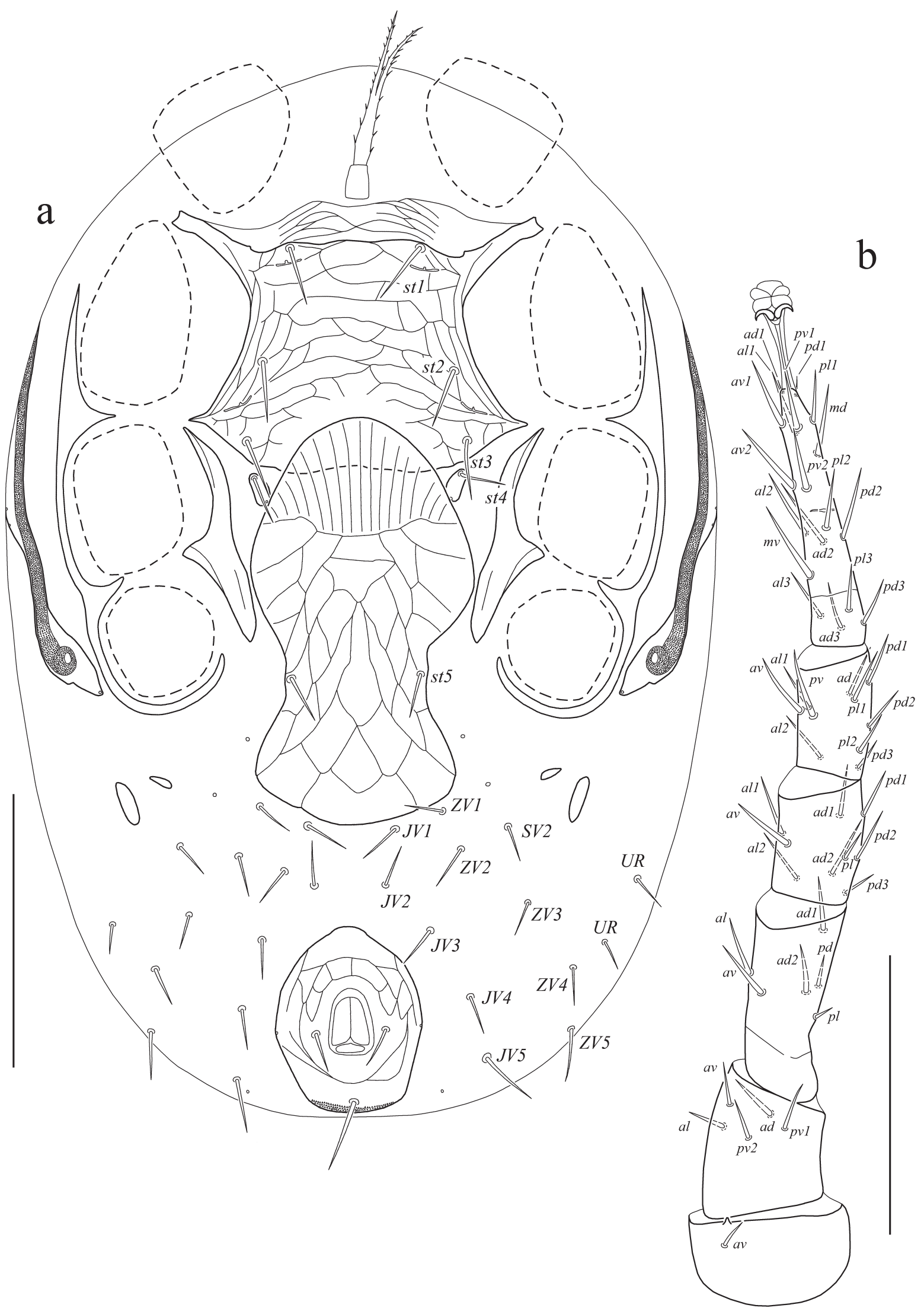

Fig. 2. Proctolaelaps dendroctoni Lindquist and Hunter, 1965, female: a-idiosoma, ventral view; b-leg IV, ventral view. Scale bars $100 \mu \mathrm{m}$. 

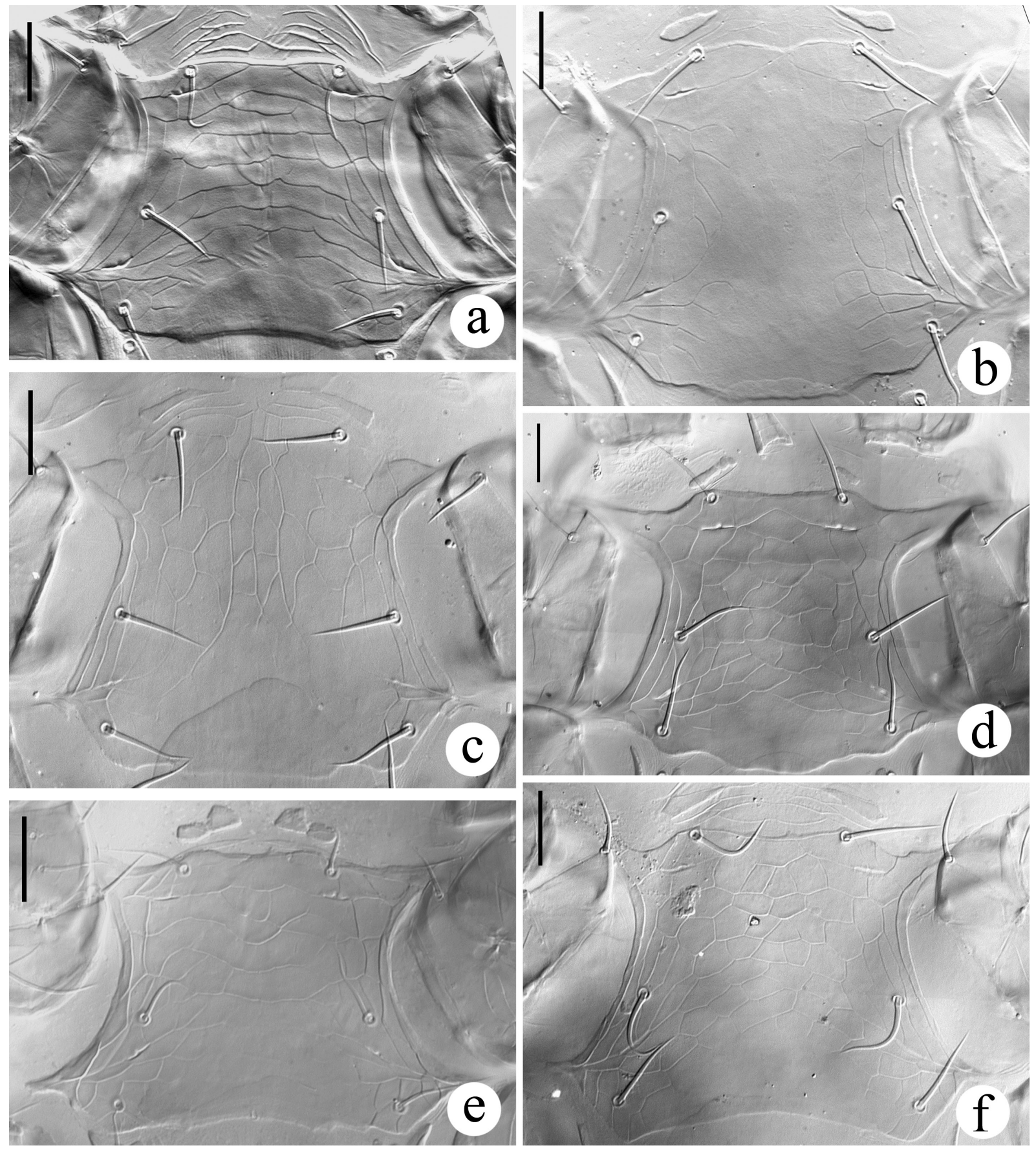

Fig. 3. Sternal shields of Proctolaelaps spp., females, DIC micrographs: a-Proctolaelaps dendroctoni Lindquist and Hunter, 1965; b-P. fiseri Samšiňák, 1960; c —P. hystricoides Lindquist and Hunter, 1965; d-P. hystrix (Vitzthum, 1923); e—P. jueradeus (Schweizer, 1949); f—P. scolyti Evans, 1958. Scale bars $25 \mu \mathrm{m}$.

para-anal setae 14-15, length of post-anal seta 23-26. Posetriad coxae IV 2 pairs of elongate metapodal platelets present; the larger platelet 14-18 long, 5-6 wide; the smaller platelet 7-8 long, 3-4 wide. Soft cuticle around of anal shield with, 13 pairs of setae (JV1-JV5, ZV1-ZV5, SV2, 2 setae of $U R$-series) and 2 pairs of distinguishable pores. All ventral setae simple; length of setae on soft cuticle (excluding JV5) 12-19, JV5 21-22. Exopodal platelets of coxae II-III, coxae III-IV and platelet en- veloping coxa IV posteriorly fused. Peritrematal shields fused with dorsal shield at transversal level between setae $s 1$ and $s 2$, free from exopodal strips, with 3 pairs of distinguishable pores; peritreme extending forward to level of $z 1$. Spermathecal apparatus not distinguishable.

Gnathosoma (Figs. 1b-e). Anterior margin of epistome narrowly rounded, denticulate (Fig. 1b). Subcapitulum 77-81 wide at widest level. Deutosternum with 6 rows of denticles, rows 1-5 con- 

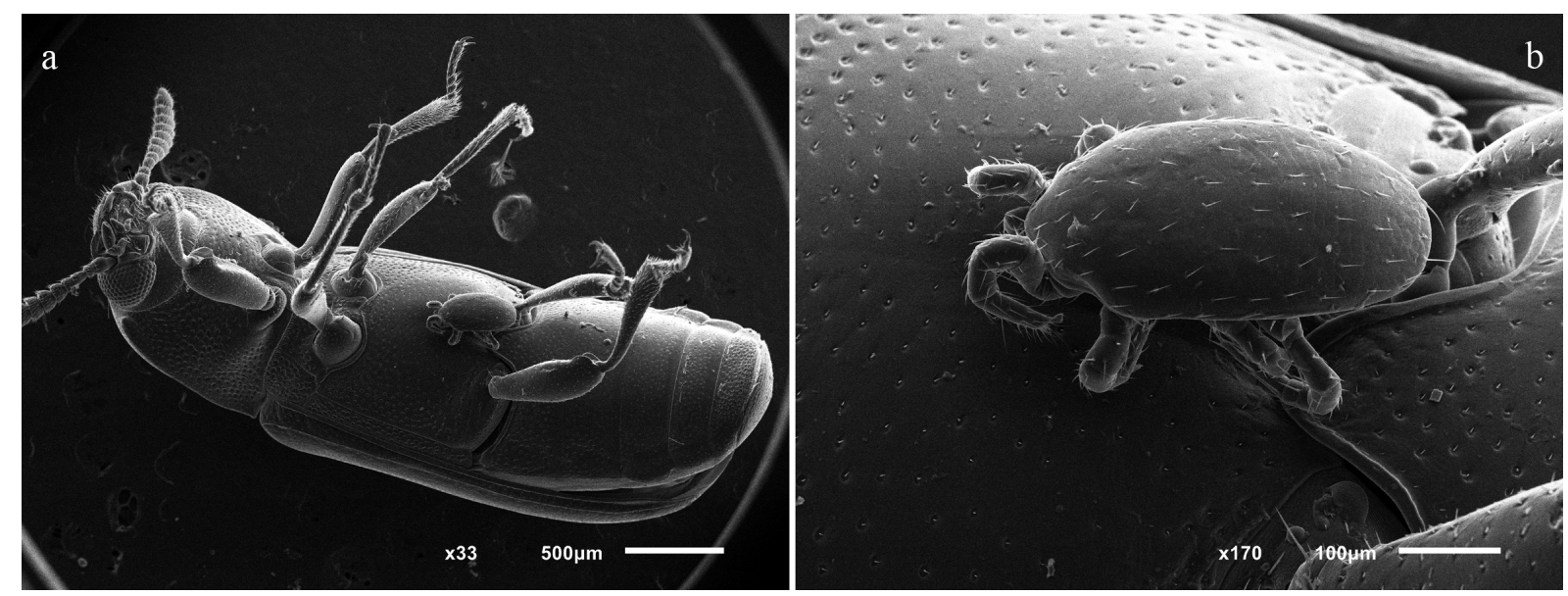

Fig. 4. Proctolaelaps dendroctoni Lindquist and Hunter, 1965, female on Corticeus sp., SEM micrographs: a—general view; b-detailed view.

nected; anterior 4 rows each with $1-3$ denticles, $5^{\text {th }}$ row widened, with $3-5$ denticles, $6^{\text {th }}$ row free, widened, with 4-5 denticles, on place of $7^{\text {th }}$ row located fragments of concave line (Fig. 1c). Hypostome with 4 pairs of simple setae; palpcoxal seta (pc) 18-20, hp1 19-20, hp2 15-16, hp3 25-27. Corniculi entire, 29-34 long, 8-11 wide, asymmetrical (one always larger than other), horn-like, sclerotized; internal malae slender, shorter than corniculi; salivary styli broad narrowing distally. Palp length from trochanter to tarsus 109-113; setal formula: 2-5-6-15-16; palpfemoral seta al and palpgenual seta al2 spatulate, palpgenual seta all weakly spatulate, palptarsal apotele 2-tined, other setae simple (Figs. 1c, d). Second cheliceral segment length 72-74, movable digit length 28-30. Fixed cheliceral digit with 5-7 teeth and membranous lobe; movable digit with 2 teeth and ventral projection (Fig. 1e).

Legs (Figs. 1f, 2b). Lengths: I 290-302, II 244-256, III 256-269, IV 336-353. Leg chaetotactic formulae normal for genus: leg I: coxa 2 , trochanter $6(10 / 11 / 21)$, femur $12(23 / 12 / 22)$, genu 13 ( $3 / 23 / 12)$, tibia $13(23 / 23 / 12)$; leg II: coxa 2 , trochanter $5(10 / 10 / 21)$, femur $11(23 / 12 / 21)$, genu $11(23 / 12 / 12)$, tibia $10(22 / 12 / 12)$, tarsus 18 (3 3/2 1/1 3/2 3); leg III: coxa 2, trochanter 5 (1 0/1 0/2 1), femur 6 (1 2/1 1/0 1), genu 9 (2 2/1 2/1 1), tibia $8(21 / 12 / 11)$, tarsus $18(33 / 21 / 13 / 23)$; leg IV: coxa 1 , trochanter $5(10 / 10 / 21)$, femur $6(1$ 2/1 1/0 1), genu $9(22 / 13 / 01)$, tibia 10 (2 1/1 3/1 $2)$, tarsus 18 (3 3/2 1/13/23). Leg segments without macrosetae (Fig. 2b); all setae smooth; setae all, $a v 1, a v 2, m v, p v 1, p v 2, p l 1$ on tarsi II-IV thickened, especially on tarsus II (Fig. 1f).

Material examined. One female, Russia, Pri-

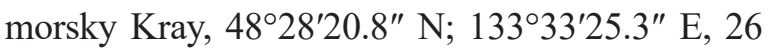

August 2016, on Corticeus sp. in galleries of Ips acuminatus (Gyllenhal, 1827) under bark of Korean pine (Pinus koraiensis), leg. A.A. Khaustov; 1 male, the same data, in galleries of Ips acuminatus.

Also, the species is registered in Crimea: 4 females, 3 males, Yalta, vicinity of Nikita settlement, $44^{\circ} 31^{\prime} \mathrm{N}, 34^{\circ} 14^{\prime} \mathrm{E}, 26$ September 1998, in galleries of Orthotomicus longicollis (Gyllenhal, 1827) (Coleoptera: Curculionidae: Scolytinae) and Rhagium inquisitor (Linnaeus, 1758) (Coleoptera: Cerambycidae) under bark of Crimean pine (Pinus nigra pallasiana), leg. A.A. Khaustov; 3 females, same locality, 2 March 1996, on Ips sexdentatus (Börner, 1776) (Coleoptera: Curculionidae: Scolytinae); 2 females, same locality, 9 May 1996, on Corticeus pini (Panzer, 1799) (Coleoptera: Tenebrionidae).

\section{PROCTOLAELAPS FISERI SAMŠIŇÁK, 1960}

Fig. $3 b$

Proctolaelaps fišeri Samšiňák, 1960, p. 297, Figs. 1-3.

Proctolaelaps yinchuanensis Bai, Yin and $\mathrm{Gu}$, 1993, p. 174, Figs. 1-5 (synonymy by Ma 2006).

This species is widely distributed in the Holarctic, where it is associated with various subcortical beetles, especially bark beetles (Samšiňák 1960; Westerboer 1963; Lindquist and Hunter 1965; Salmane 2007; Gwiazdowicz 2008; Hofstetter et al. 2015). In addition, it was recorded in European Russia in the galleries of Hylastes opacus Erichson, 1836, Tomicus piniperda (Linnaeus, 1758), Ips typographus Linnaeus, 1758, Pityogenes chalcographus (Linnaeus, 1761) (Andreev 1988; Maslov and Matusevich 2008) and in Western Siberia (Davydova and Nikolsky 1986). The errone- 
ous identification of P. fiseri on Pityogenes chalcographus from Western Siberia by Khaustov et al. (2016) is corrected here to Proctolaelaps hystricoides Lindquist and Hunter, 1965.

Material examined. Four females, Russia, Tomsk Region, vicinity of Zavarzino settlement, $56^{\circ} 27^{\prime} 55.7^{\prime \prime} \mathrm{N}, 085^{\circ} 06^{\prime} 55.6^{\prime \prime} \mathrm{E}, 22$ December 2014, on Polygraphus proximus Blandford, 1894 and in its galleries under bark of Siberian fir (Abies sibirica), leg. I.A. Kerchev; 7 females, Russia, Tomsk Region, Tomsk District, vicinity of Tomsk, $56^{\circ} 29^{\prime}$ N, 84 $57^{\circ}$ E, 31 May-2 June 2016, on Polygraphus proximus and in its galleries under bark of Siberian fir, leg. A.A. Khaustov; 2 females, same data, ex Tetropium sp. (Coleoptera: Cerambycidae) under bark of Siberian pine (Pinus sibirica), leg. I.A. Kerchev; 1 female, Russia, Tyumen Region, Tyumen District, vicinity of Uspenka settlement, $57^{\circ} 04^{\prime}$ $\mathrm{N}, 65^{\circ} 04^{\prime} \mathrm{E}$, 14 June 2016, in galleries of Ips typographus under bark of Siberian spruce (Picea obovata), leg. A.A. Khaustov; 1 female, Russia, Khanty-Mansi Autonomous Okrug, Oktyabrsky District, vicinity of Oktyabrskoye, $62^{\circ} 27^{\prime} \mathrm{N}, 66^{\circ} 04^{\prime}$ E, 11 August 2016, in galleries of Hylurgops glabratus (Zetterstedt, 1828) under bark of Siberian spruce, leg. A.A. Khaustov; 1 female, Russia, Primorsky Kray, 48²8'20.8" N; 133³3'25.3" E, 26 August 2016, in galleries of Ips acuminatus under bark of Korean pine (Pinus koraiensis), leg. A.A. Khaustov; 10 females, Russia, Primorsky Kray, vicinity of Lazo settlement, $43^{\circ} 30^{\prime} \mathrm{N}, 133^{\circ} 34^{\prime}$ E, 26-28 August 2016, in galleries of Polygraphus proximus under bark of Khingan fir (Abies nephrolepis), leg. A.A. Khaustov; 2 females, Russia, Tyumen Region, Nizhnetavdinsky District, vicinity of Tyunevo settlement, $57^{\circ} 23^{\prime} \mathrm{N}, 65^{\circ} 41^{\prime}$ E, 7 October 2016, in galleries of Polygraphus subopacus Thomson, 1871 under bark of Siberian spruce, leg. A.A. Khaustov; 4 females, Russia, Sakhalin Region, Sakhalin Island, Yuzhno-Sakhalinsk, 3 August 2017, in galleries of Polygraphus proximus under bark of Sakhalin fir (Abies sachalinensis), $46^{\circ} 54^{\prime} 40.3^{\prime \prime} \mathrm{N}$; $142^{\circ} 46^{\prime} 03.9^{\prime \prime}$ E, leg. A.A. Khaustov; 4 females, 1 male, Russia, Sakhalin Region, $\mathrm{Ku}-$ nashir Island, in galleries of Polygraphus proximus under bark of Sakhalin fir, $44^{\circ} 00^{\prime} 30.0^{\prime \prime} \mathrm{N}$; 14541'39.7" E, 5 August 2017, leg. A.A. Khaustov; 6 females, 1 male, Russia, Sakhalin Region, Kunashir Island, in galleries of Ips typographus japonicus Niisima, 1909 under bark of Sakhalin

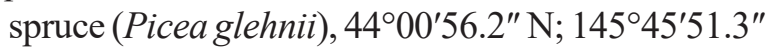
E, 8 August 2017, leg. A.A. Khaustov; 4 females, Russia, Sakhalin Region, Sakhalin Island, in gal- leries of Ips typographus under bark of Sakhalin spruce, $46^{\circ} 47^{\prime} 04.9^{\prime \prime} \mathrm{N}$; $142^{\circ} 23^{\prime} 13.0^{\prime \prime} \mathrm{E}, 13$ August 2017, leg. A.A. Khaustov.

\section{PROCTOLAELAPS HYSTRICOIDES LINDQUIST AND HUNTER, 1965}

Fig. $3 \mathrm{c}$

Proctolaelaps hystricoides Lindquist and Hunter, 1965, p. 22, Figs. 11-19.

Type series of $P$. hystricoides included specimens from Canada and the USA. The mites were found in galleries of many Scolytinae beetle species, under the bark of pines. Later, this species was recorded in soil samples from Iran (references in Kazemi and Rajaei 2013). Hadad Iraninezhad et al. (2001) reported this species in Iranian cotton fields. These mites also occur on bark beetles Pityokteines spp. that live on Silver fir (Abies alba) in Croatia (Pernek et al. 2008). This is a new record for the fauna of Russia.

Material examined. Two females, Russia, Tomsk Region, Tomsk District, vicinity of Tomsk, $56^{\circ} 29^{\prime} \mathrm{N}, 84^{\circ} 57^{\prime}$ E, 31 May 2016, on Polygraphus proximus under bark of Siberian fir, leg. A.A. Khaustov; 2 females, same locality, 28 April 2017, in galleries of Polygraphus proximus under bark of Siberian fir, leg. A.A. Khaustov; 9 females, Russia, Tyumen Region, Tyumen District, vicinity of Uspenka settlement, $57^{\circ} 04^{\prime} \mathrm{N}, 65^{\circ} 04^{\prime} \mathrm{E}, 29$ April-5 May 2016, on Pityogenes chalcographus under bark of Siberian spruce (Picea obovata), leg. A.A. Khaustov; 1 female, same locality, 5 June 2017, in alcohol sediments of tree traps together with Ips typographus; 6 females, Russia, Khanty-Mansi Autonomous Okrug, Oktyabrsky District, vicinity of Oktyabrskoye settlement, $62^{\circ} 27^{\prime} \mathrm{N}, 66^{\circ} 04^{\prime} \mathrm{E}$, 11 August 2016, in galleries of Hylurgops glabratus under bark of Siberian spruce, leg. A.A. Khaustov; 1 female, Russia, Primorsky Kray, vicinity of Lazo settlement, $43^{\circ} 30^{\prime} \mathrm{N}, 133^{\circ} 34^{\prime} \mathrm{E}, 26$ August 2016, in galleries of Polygraphus proximus under bark of Khingan fir, leg. A.A. Khaustov; 11 females, Russia, Primorsky Kray, Vladivostok city, 43 ${ }^{\circ} 13^{\prime}$ N, 131 ${ }^{\circ} 59^{\prime}$ E, 29 August 2016, in galleries of Polygraphus proximus under bark of Manchurian fir (Abies holophylla), leg. A.A. Khaustov; 6 females, 1 male, Altai Republic, 51 ${ }^{\circ} 53^{\prime} 12.1^{\prime \prime} \mathrm{N}$, $086^{\circ} 11^{\prime 2} 23.9^{\prime \prime} \mathrm{E}$, in galleries of Polygraphus proximus under bark of Siberian fir, leg. A.A. Khaustov; 3 females, one male, Altai Republic, $52^{\circ} 00^{\prime} 13,4^{\prime \prime} \mathrm{N}, 086^{\circ} 33^{\prime} 04,9^{\prime \prime} \mathrm{E}$, in galleries of Polygraphus proximus under bark of Siberian fir, 
leg. A.A. Khaustov; 2 females, 1 male, Altai Republic, $51^{\circ} 18^{\prime} 53,9^{\prime \prime} \mathrm{N}, 085^{\circ} 40^{\prime} 25.0^{\prime \prime} \mathrm{E}$, in galleries of Ips subelongatus Motchulsky, 1860 under bark of Siberian larch (Larix sibirica), leg. A.A. Khaustov; 4 females, 1 male, Russia, Sakhalin Region, Sakhalin Island, 4651'59.2" N, 142 ${ }^{\circ} 52^{\prime} 42.7^{\prime \prime}$ E, in galleries of Ips subelongatus under bark of Kuril larch (Larix kurilensis), leg. A.A. Khaustov.

\section{PROCTOLAELAPS HYSTRIX (VITZTHUM, 1923)}

Fig. 3d

Lasioseius (Lasioseius) hystrix Vitzthum, 1923, p. 105, Figs. 8, 9.

Proctolaelaps (Proctolaelaps) hystrix.-Evans, 1958, p. 200.

P. hystrix was described from Austria from the galleries of Dendroctonus micans (Kugelann, 1794) and Hylastes ater Paykull, 1800 (Coleoptera: Curculionidae: Scolytinae) (Vitzthum 1923). Currently, this species is known from Europe, North America and Australia (Lindquist and Hunter 1965; Halliday et al. 1998; Fend'a and Mašán 2003; Salmane 2005; Gwiazdowicz 2008; Chaires-Grijalva et al. 2016). This is a new record for the fauna of Russia.

Material examined. Twelve females, 1 male, Russia, Tyumen Region, vicinity of Omutinsky settlement, 56 $35^{\prime} 11^{\prime \prime} \mathrm{N}, 67^{\circ} 42^{\prime} 55^{\prime \prime}$ E, 18 August 2016, in galleries of Dendroctonus micans under bark of Scots pine (Pinus silvestris), leg. A.A. Khaustov.

\section{PROCTOLAELAPS JUERADEUS (SCHWEIZER, 1949)}

Fig. 3e

Lasioseius jüradeus Schweizer, 1949, p. 52, Fig. 30.

Proctolaelaps jüradeus.-Karg, 1971, p. 240.

Proctolaelaps (Proctolaelaps) robustus Evans, 1958, p. 203, Figs. 39-40 (synonymy by Bregetova, 1977).

This species is widely distributed in the Holarctic (including Russia). It is associated with soil and related substrates (Schweizer 1949; Evans 1958; Chant 1963; Westerboer 1963; Bregetova 1977; Karg 1993; Salmane 2001; Marchenko 2002, 2012; Gwiazdowicz 2008; Makarova 2012). Previously, P. jueradeus had never been reported as an associate of bark beetles.

Material examined. One female, Russia, Tyumen Region, Tyumen District, vicinity of Uspenka settlement, $57^{\circ} 04^{\prime} \mathrm{N}, 65^{\circ} 04^{\prime} \mathrm{E}, 22$ May 2017 , in alcohol sediments of tree traps together with Ips typographus, leg. A.A. Khaustov.

\section{PROCTOLAELAPS SCOLYTI EVANS, 1958}

Fig. $3 \mathrm{f}$

Proctolaelaps (Proctolaelaps) scolyti Evans, 1958, p. 201, Figs. 36-38.

Proctolaelaps ulmi Hirschmann, 1962, p. 30, Fig. 13 (2).

Garmania (Garmania) ulmi Hirschmann, in Westerboer, 1963, p. 391, Figs. 231-238 (synonymy by Karg 1988).

This species is distributed in Europe, as well as Western and Central Asia. P. scolyti is mainly associated with bark beetles. The species has been recorded on sap beetles Carpophilus hemipterus (Linnaeus, 1758), as well as in soil, hollow trees, under bark, and in bird nests (Evans 1958; Westerboer 1963; Rybin 1983; Salmane 2005; Fend'a 2010; Çakmak et al. 2011). This is a new record for the fauna of Russia.

Material examined. Three females, Russia, Khanty-Mansi Autonomous Okrug, Oktyabrsky District, vicinity of Oktyabrskoye settlement, $62^{\circ} 27^{\prime} \mathrm{N}, 66^{\circ} 04^{\prime} \mathrm{E}, 11$ August 2016, in galleries of Scolytus ratzeburgi Janson, 1856 under bark of Silver birch (Betula pendula), leg. A.A. Khaustov.

\section{Key to females of Proctolaelaps associated with subcortical beetles}

1. Anus small, length of anal shield exceeding length of anal opening by 3.5 or more times ......2

- Anus large, length of anal shield exceeding length of anal opening by $2-3$ times .................... 6

2. Setae $j 1-j 5$ not less than 2.5 times shorter than setae J1-J4 [Western Palaearctic: Europe] ... P. xyloteri Samšiňák, 1960; P. kielczewskii Wisniewski, 1980; P. moseri Wisniewski, 1980*

- Setae $j 1-j 5$ similar in length to setae $J 1-$ $J 4 \ldots$

3. Pre-sternal area without platelets. Dorsal shield elongated-oval [Western Palaearctic: Europe] ........... P. eccoptogasteris (Vitzthum, 1923); P. pruni Karg, $1988^{* *}$

- Pre-sternal area with 1 or 2 pairs of platelets. Dorsal shield oval

4. Pre-sternal area with 2 pairs of platelets (Fig. 3e). Epistomal margin denticulate. Fixed cheliceral digit with pilus dentilis [Holarctic]. P. jueradeus (Schweizer, 1949) 
- Pre-sternal area with one pair of platelets. Epistomal margin smooth. Pilus dentilis absent ....5

5. Length of anal shield exceeding length of anal opening by 3.5 times; anus located in central part of shield [Western Palaearctic: Europe].......... P. cyllodi Samšiňák, 1960

- Length of anal shield exceeding length of anal opening by 5 times; anus located in posterior part of shield [Western Palaearctic: Slovakia] ...... ..P. slovacus Mašán, 1998

6. Epistome tri-ramous or bi-ramous ... 7

- Epistomal margin denticulate 10

7. Setae $j 3-j 5$ short, 1.5-2 times shorter than setae $J 2-J 4$. Setae $Z 5$ curved, thickened. Post-anal seta very short, 2 times shorter than seta JV5 [Australasia: Ausralia] P. australis Stone, 1988

- Setae j3-j5 and J2-J4 subequal in length. Setae $Z 5$ simple. Post-anal seta equal to or longer than seta $J V 5$.

8. Setae of $j-J$-series longer, seta $j 4$ as long as distance to seta $j 5$, seta $J 3$ as long as distance to seta J4 [Palaearctic; Nearctic; Australasia]. P. hystrix (Vitzthum, 1923)

- Setae of $j-J$-series shorter, seta $j 4$ shorter than distance to seta $j 5$, seta $J 3$ shorter than distance to seta $J 4$

9. Sternal shield smooth in central part (Fig. 3b). Setae $s t 1$ not close together, distance st1-st 1 longer than distance st 1-st2 [Holarctic]

P. fiseri Samšiňák, 1960

- Sternal shield medially with longitudinal row of elongated cells (Fig. 3c). Setae st 1 close together, distance $s t 1-s t 1$ shorter or equal to distance st 1-st2 [Holarctic].

.P. hystricoides Lindquist and Hunter, 1965

10. Dorsal setae shorter, length of setae $J 1-J 3$ shorter than half distance to subsequent seta .... 11

- Dorsal setae longer, length of setae $J 1-J 3$ subequal or equal distance to subsequent seta......13

11. Pre-sternal area with a pair of platelets. Subcapitular setae $p c$ thickened basally [Nearctic; Northern Neotropics: Honduras]...

P. subcorticalis Lindquist, 1971

- Pre-sternal area without platelets (Fig. 3a). Subcapitular setae $p c$ simple. 12

12. Fixed cheliceral digit with 13 teeth, movable digit with 4 teeth. $7^{\text {th }}$ row of hypostomal groove well developed, with 6 denticles. Epistomal margin with irregular dentate projections [Western Palaearctic: Europe] .................. P. brevipilis (Westerboer, 1963)

- Fixed cheliceral digit with 5-7 teeth, movable digit with 2 teeth. $7^{\text {th }}$ row of hypostomal groove absent. Epistomal margin with small uniform denticles [Holarctic] ..P. dendroctoni Lindquist and Hunter, 1965

13. Seta j6 reaching base of seta $J 1$........... 14

— Seta j6 not reaching base of seta $J 1$....... 18

14. Fixed cheliceral digit with 4 teeth and pilus dentilis; movable digit with 1 tooth [Palaearctic]. P. stammeri (Westerboer, 1963)

- Fixed cheliceral digit with 7 or more teeth, pilus dentilis absent; movable digit with $2-3$ teeth........... 15

15. Fixed cheliceral digit with 7 teeth. Anal shield long, almost reaching epigynal shield anteriorly; anal opening located mainly in posterior region of shield [Palaearctic]

P. longanalis (Westerboer, 1963)

— Fixed cheliceral digit with about 20 teeth. Anal shield of normal length; anal opening located mainly in anterior region of shield ..................... 16

$16.1-4^{\text {th }}$ rows of hypostomal groove each with 7-10 denticles. Epistomal margin with about 40 denticles [Western Palaearctic: Europe]

P. pini Hirschmann, 1962

$-1-4^{\text {th }}$ rows of hypostomal groove each with 1-4 denticles. Epistomal margin with about 10 denticles .17

17. Anterior margin of epistome semi-triangular, with closely disposed middle-sized denticles. Internal malae longer than corniculi [Western Palaearctic: Europe] .................. P. epuraeae Hirschmann, 1962

- Anterior margin of epistome rounded, with sparsely spaced small denticles. Internal malae shorter than corniculi [Western Palaearctic: Europe, Asian Turkey]....... P. rotundus Hirschmann, 1962

18. Fixed cheliceral digit with about 25 teeth and dorsodistal pointed process; movable digit with $3-5$ teeth. $1-4^{\text {th }}$ rows of hypostomal groove each with about 10 denticles [Eastern Palaearctic: Japan] ....................... nipponicus Ishikawa, 1968

- Fixed cheliceral digit with about 15 teeth, dorsodistal process absent; movable digit with 2-3 teeth. 1-4 $4^{\text {th }}$ rows of hypostomal groove each with 0-3 denticles 19

19. Setae $j 1, J 4, Z 3-Z 5$ subequal in length. $5^{\text {th }}$ row of hypostomal groove medially smooth; $7^{\text {th }}$ row absent. Internal malae shorter than corniculi [Neotropics: Chile] ............P. ruehmi Hirschmann, 1972

- Seta Z5 1.5-2 times as long as setae $j 1, \mathrm{~J} 4$, $Z 3, Z 4.5^{\text {th }}$ row of hypostomal groove medially with 1 or several denticles; $7^{\text {th }}$ row present. Internal malae longer than corniculi...............................20

20. Sternal shield medially smooth. Epigynal shield with pointed triangular anterior flap extending to level of setae st2. Epistomal margin triangu- 
lar, denticulate. Postgenital platelets present [Cosmopolitan] P. bickleyi (Bram, 1956)

- Sternal shield medially reticulate (Fig. 3f). Epigynal shield with rounded anterior flap extending to level of setae st3. Epistomal margin rounded, denticulate. Postgenital platelets absent [Palaearctic] ..................................... scolyti Evans, 1958

Notes:

${ }^{*}$ Gwiazdowicz (2007) suspected P. kielczewskii and $P$. moseri to be junior synonyms of $P$. xyloteri.

${ }^{* *}$ Gwiazdowicz (2007) suspected $P$. pruni to be a junior synonym of $P$. eccoptogasteris.

\section{ACKNOWLEDGEMENTS}

Deep appreciation is due to Dr. Evert E. Lindquist (Canadian National Collection of Insects, Arachnids, and Nematodes, Science and Technology Branch, Agriculture and Agri-Food Canada, Ottawa, Canada) for the information about the morphology of Proctolaelaps dendroctoni; to Dr. Bruce R. Halliday (Australian National Insect Collection, CSIRO, Canberra, Australia) for sending important copies of papers for the present work; to Dr. Olga L. Makarova (A.N. Severtsov Institute of Ecology and Evolution, Moscow, Russia) for her numerous suggestions on how to improve this paper; to Dr. Mikhail Ju. Mandelshtam (Center for Bioinformatics and Genome Research, Saint-Petersburg S.M. Kirov State Forest Technical University, Saint-Petersburg, Russia) for his help in collecting material and identifying the bark beetles; to Roman V. Latyntsev (Tyumen State University, Russia) for logistics; and to Andrei N. Bobylev (Tyumen State University) for preparing the SEM photos. This research was supported by the grant from the Russian Science Foundation, project No. 16-14-10109 to Dr. Alexander A. Khaustov.

\section{REFERENCES}

Abo-Shnaf, R.I.A. and Moraes, G.I. de. 2016. Proctolaelaps species (Acari: Mesostigmata: Melicharidae) from Egypt, with description of a new species and complementary descriptions of other five species. Zootaxa, 4162 (3): 479-503. http://doi. org/10.11646/zootaxa.4162.3.4

Andreev, E.A. 1988. On the fauna and ecology of mites of the genus Proctolaelaps (Aceosejidae) from galleries of bark beetles in the Moscow Province. Biologicheskie Nauki, 10: 34-37. [In Russian]

Bai, X.-L., Yin, S.-G., and Gu, Y.-M. 1993. A new species and a new record of the genus Proctolaelaps from China (Acari: Blattisocidae). Acta Zootaxonomica Sinica, 18, 174-176. [In Chinese]
Bregetova, N.G. 1977. Fam. Aceosejidae Baker and Wharton, 1952 (sensu Evans, 1958). In: M.S. Ghilyarov and N.G. Bregetova (Eds.). Key to the SoilInhabiting Mites. Mesostigmata. Leningrad, Nauka, pp. 169-226. [In Russian]

Çakmak, I., Faraji, F., and Çobanoğlu, S. 2011. A checklist and key to the Ascoidea and Phytoseioidea (except Phytoseiidae) species of Turkey with three new species records (Acari: Mesostigmata). Türkiye Entomoloji Dergisi, 35: 575-586.

Chaires-Grijalva, M.P., Estrada-Venegas, E.G., Equihua-Martínez, A., Moser, J.C., Sánchez-Martínez, G., Vázquez-Rojas, I.M., Otero-Colina, G., and Romero-Nápoles, J. 2013. Mesostigmados (Acari: Mesostigmata) asociados con Dendroctonus rhizophagus de Chihuahua, México. Revista Mexicana de Biodiversidad, 84: 1235-1242. [In Spanish] http://doi.org/10.7550/rmb.35723

Chant, D.A. 1963. The subfamily Blattisocinae Garman (Aceosejinae Evans) (Acarina: Blattisocidae Garman) (Aceosejidae Baker and Wharton) in North America, with descriptions of a new species. $\mathrm{Ca}$ nadian Journal of Zoology, 41: 243-305. http:// dx.doi.org/10.1139/z63-025

Costa, M. 1963. The mesostigmatic mites associated with Copris hispanus (L.) (Coleoptera, Scarabaeidae) in Israel. Journal of the Linnean Society of London, Zoology, 45: 25-45. http://dx.doi. org/10.1111/j.1096-3642.1963.tb00485.x

Davydova, M.S. 1988. New species of gamasid mites associated with bumble bees. Novye i Maloizvestnye Vidy Fauny Sibiri, 20: 18-32. [In Russian]

Davydova, M.S. and Nikolsky, V.V. 1986. Gamazovye kleshchi Zapadnoy Sibiri [Gamasid mites of West Siberia]. Nauka, Novosibirsk, 123 pp. [In Russian]

De Leon, D. 1963. New genus and twelve new species of mites from Mexico and southeast United States (Acarina: Blattisociidae). The Florida Entomologist, 46: 197-207. http://dx.doi.org/10.2307/3493632

Evans, G.O. 1958. A revision of the British Aceosejinae (Acarina: Mesostigmata). Proceedings of the Zoological Society of London, 131: 177-229. http:// dx.doi.org/10.1111/j.1096-3642.1958.tb00685.x

Evans, G.O. 1963a. Observations on the chaetotaxy of the legs in the free-living Gamasina (Acari: Mesostigmata). Bulletin of the British Museum (Natural History), Zoology, 10: 277-303. https://doi. org/10.5962/bhl.part.20528

Evans, G.O. 1963b. Some observations on the chaetotaxy of the pedipalps in the Mesostigmata (Acari). Annals and Magazine of Natural History, Series 13, 6: 513527. http://dx.doi.org/10.1080/00222936308651393

Evans, G.O. 1969. Observations on the ontogenetic development of the chaetotaxy of the tarsi of legs II-IV in 
the Mesostigmata (Acari). In: G.O. Evans (Ed.). Proceedings of the $2^{\text {nd }}$ International Congress of Acarology, 1967. Akadémiai Kiadó, Budapest, pp. 195-200.

Evans, G.O. and Till, W.M. 1979. Mesostigmatic mites of Britain and Ireland (Chelicerata: Acari-Parasitiformes). An introduction to their external morphology and classification. Transactions of the Zoological Society of London, 35: 139-270. http:// dx.doi.org/10.1111/j.1096-3642.1979.tb00059.x

Fain, A., Hyland, K.E., and Aitken, T.H.G. 1977. Flower mites of the family Ascidae phoretic in nasal cavities of birds (Acarina: Mesostigmata). Acta Zoologica et Pathologica Antverpiensia, 69: 99-154.

Faraji, F. 2011. A new species of Proctolaelaps Berlese (Acari: Melicharidae) associated with the nest of European starling Sturnus vulgaris. Revista Ibérica de Acarologia, 19: 23-26.

Fend'a, P. 2010. Mites (Mesostigmata) inhabiting bird nests in Slovakia (Western Carpathians). In: M.W. Sabelis and J. Bruin (Eds.). Trends in Acarology. Proceedings of the $12^{\text {th }}$ International Congress. Springer Science and Business Media B.V., Dordrecht, Heidelberg, London, New York, pp. 199-205.

Fend'a, P. and Mašán, P. 2003. Roztoče, Acari (Parasitiformes, ex. Uropodina). In: P. Mašán and J. Svatoň (Eds.). Pavúkovce Národného parku Poloniny, Arachnids of the Poloniny National Park (Arachnida: Araneae, Pseudoscorpiones, Opiliones, Acari-Parasitiformes). Štátna ochrana prírody SR Banská Bystrica a Správa Národného parku Poloniny, Snina, pp. 143-205.

Gwiazdowicz, D. J. 2007. Ascid Mites (Acari, Mesostigmata) from Selected Forest Ecosystems and Microhabitats in Poland. Wydawnictwo Akademii Rolniczej im. Augusta Cieszkowskiego, Poznan, 248 pp.

Gwiazdowicz, D.J. 2008. Mesostigmatid mites (Acari) associated with Scolytidae in Poland. In: D.J. Gwiazdowicz (Ed.). Selected problems of acarological research in forests. Wydawnictwo Uniwersytetu Przyrodniczego, Poznan, pp. 59-95.

Hadad Iraninezhad, K., Kamali, K., and Maleki Milani, H. 2001. Mites of Digamasellidae, Rhodacaridae, Phytoseiidae and Ascidae of the cotton fields in Moghan Plain. Agricultural Sciences and Technology, 15 (1): 23-33.

Halliday, R.B. 2001. Mesostigmatid mite fauna of Jenolan Caves, New South Wales (Acari: Mesostigmata). Australian Journal of Entomology, 40: 299-311. http://dx.doi.org/10.1046/j.1440-6055.2001.00247.x

Halliday, R.B., Walter, D.E., and Lindquist, E.E. 1998. Revision of the Australian Ascidae (Acarina: Mesostigmata). Invertebrate Taxonomy, 12: 1-54. http://dx.doi.org/10.1071/IT96029
Hanekom, A., Loots, G.C., and Theron, P.D. 1988. Two new species of Proctolaelaps (Ascidae: Acari) from the Afrotropical region with notes on $P$. oudemansi Krantz, 1962. Phytophylactica, 20: 25-29.

Hirschmann, W. 1962. Gangsystematik der Parasitiformes. Teil 5. Gamasiden Rückenhaarbestimmungstafeln von 260 Typhlodromus-Arten der Erde. Gänge, Chaetotaxie, Porotaxie, Mundwerkzeuge von Typhlodromus und verwandten Gattungen von Proctolaelaps, Melichares, Lasioseius, Iphidozercon, Sejus, Rhodacarellus, Rhodacarus, Gamasellus, Veigaia, Macrocheles ivanovi. Erstversuch der Aufstellung eines Gangsystems der Gamasiden aufgrund der Gnathosomaunterseite. Acarologie. Schriftenreihe für Verglenchende Milbenkunde, 5: 1-56.

Hirschmann, W. 1972. Gangsystematik der Parasitiformes. Teil 104. Von Dr. W. Rühm während seiner Tätigkeit an der Univ. Austral de Chile (Valdivia) gesammelte Araukarien-Milben aus Südchile u. Südbrasilien. Acarologie. Schriftenreihe für Verglenchende Milbenkunde, 17: 29-33.

Hofstetter, R.W., Dinkins-Bookwalter, J., Davis, T.S., and Klepzig, K.D. 2015. Symbiotic associations of bark beetles. In: F.E. Vega and R.W. Hofstetter (Eds.). Bark Beetles, Biology and Ecology of Native and Invasive species. 1st ed. Elsevier Academic Press, pp. 209-245.

Ishikawa, K. 1968. Studies on the mesostigmatid mites associated with the insects in Japan (I). Reports of Research Matsuyama Shinonome Junior College, 3: 197-218.

Karg, W. 1971. Acari (Acarina), Milben, Unterordnung Anactinochaeta (Parasitiformes). Die freilebenden Gamasina (Gamasides), Raubmilben. Die Tierwelt Deutschlands, 59. Gustav Fischer Verlag, Jena, 475 pp.

Karg, W. 1985. Die Raubmilbengattung Proctolaelaps Berlese, 1923. Zoologische Jahrbücher Abteilung für Systematik, Ökologie und Geographie der Tiere, 112: 185-206.

Karg, W. 1988a. Zur Kenntnis der Gattung Proctolaelaps Berlese, 1923 (Acarina, Parasitiformes). Zoologische Jahrbücher Abteilung für Systematik, Ökologie und Geographie der Tiere, 115: 441-454.

Karg, W. 1988b. Eine neue Raubmilbenart der Gattung Proctolaelaps Berlese, 1923 (Acarina, Parasitiformes) am Grossen Obstbaumsplintkäfer (Scolytus (Eccoptogaster) mali Bechest.). Archiv für Phytopathologie und Pflanzenschutz, 24: 515-517. http://dx.doi.org/10.1080/03235408809437850

Karg, W. 1993. Acari (Acarina), Milben Parasitiformes (Anactinochaeta), Cohors Gamasina Leach, Raubmilben. Die Tierwelt Deutschlands und der angren- 
zenden Meeresteile nach ihren Merkmalen und ihrer Lebensweise, 59 (2), überarbeitete Auflage. Gustav Fischer Verlag, Jena, Stuttgart, New York, 523 pp.

Kazemi, S. and Rajaei, A. 2013. An annotated checklist of Iranian Mesostigmata (Acari), excluding the family Phytoseiidae. Persian Journal of Acarology, 2: 63-157.

Khaustov, A.A., Trach, V.A., and Bobylev, A.N. 2016. Mites (Acari) phoretic on six-toothed spruce bark beetle, Pityogenes chalcographus Linnaeus (Coleoptera: Curculionidae: Scolytinae) in Western Siberia, Russia. Acarina, 24: 137-151. http:// dx.doi.org/21684/0132-8077-2016-24-2-137-151

Kinn, D.N. 1983. The life cycle of Proctolaelaps dendroctoni Lindquist and Hunter (Acari: Ascidae): a mite associated with pine bark beetles. International Journal of Acarology, 9: 205-210. http:// dx.doi.org/10.1080/01647958308683338

Klimov, P.B. 1998. To the knowledge of mites and ticks (Acari) of Kuril Islands. Far Eastern Entomologist, 36: $1-36$.

Lindquist, E. E. 1971. New species of Ascidae (Acarina: Mesostigmata) associated with forest insect pests. The Canadian Entomologist, 103: 919-942. http://dx.doi.org/10.4039/Ent103919-7

Lindquist, E.E. 1994. Some observations on the chaetotaxy of the caudal body region of gamasine mites (Acari: Mesostigmata), with a modified notation for same ventrolateral body setae. Acarologia, 35: 323-326.

Lindquist, E.E. and Evans G.O. 1965. Taxonomic concepts in the Ascidae, with a modified setal nomenclature for the idiosoma of the Gamasina (Acarina: Mesostigmata). Memoirs of the Entomological Society of Canada, 47: 1-65. http://dx.doi. org/10.4039/entm $9747 \mathrm{fv}$

Lindquist, E.E. and Hunter, P.E. 1965. Some mites of the genus Proctolaelaps Berlese (Acarina: Blattisociidae) associated with forest insect pests. The Canadian Entomologist, 97: 15-32. https:// dx.doi. org/10.4039/Ent9715-1

Literakova, Z., Literak, I., and Kaluz S. 2016. Mites Proctolaelaps superagui sp. nov. and Tropicoseius braziliensis on bromeliad Quesnelia arvensis in Brazil. International Journal of Acarology, 42: 265-273. http://dx.doi.org/10.1080/01647954.20 16.1182212

Ma, L.-M. 2006. New synonyms of gamasid mites (Acari: Mesostigmata). Acta Arachnologica Sinica, 15, 23-26. [In Chinese]

Ma, L.-M., Zhang, A. H., Li, Y.R. 2003. Two new species of the genus Hypoaspis and a new species of the genus Melichares associated with insects (Acari:
Gamasina: Laelapidae and Aceosejidae). Acta Arachnologica Sinica, 12: 72-78. [In Chinese]

Makarova, O.L. 2009. The fauna of free-living gamasid mites (Parasitiformes, Mesostigmata) in the northern taiga: an analysis of the zonal specificity. Entomological Review, 89: 1177-1193. https://doi. org/10.1134/S0013873809090176

Makarova, O.L. 2011. A review of gamasid mites (Parasitiformes, Mesostigmata) in the taiga of the Pechoro-Ilychski Nature Reserve (Northern Cisuralia) with an analysis of their assemblages in spruce forests. Zoologicheskii Zhurnal, 90: 649664. [In Russian]

Makarova, O.L. 2012. Gamasid mites (Parasitiformes, Mesostigmata) of the European Arctic and their distribution patterns. Entomological Review, 93: 113-133. https://doi.org/10.1134/S0013873813010156

Marchenko, I.I. 2002. Faunistic review of free-living Gamasina mites (Acari, Mesostigmata) from Sakhalin and Kuril Islands. Euroasian Entomological Journal, 1: 31-48.

Marchenko, I.I. 2012. Spatial-typological organization of the soil Gamasina mite (Acari, Mesostigmata) community of Northeastern Altai. Communication II. Contemporary Problems of Ecology, 5 (1): 23-33. https://doi.org/10.1134/S1995425512010031

Marchenko, I.I. 2017. Soil gamasid mites (Acari, Mesostigmata) of Sokhondinskii Nature Reserve, Zabaikalskii Krai, Russia. Euroasian Entomological Journal, 162): 151-157. [In Russian]

Mašán, P. 1998. Two new mesostigamatic mites (Acarina, Proctolaelaps, Hypoaspis) associated with erotylid and melolonthine beetles (Coleoptera: Erotylidae, Scarabaeidae) from Slovakia. Entomological Problems, 29: 19-22.

Mašán, P., Perotti, M.A., Saloña-Bordas, M.I., and Braig, H.R. 2013 Proctolaelaps euserratus, an ecologically unusual melicharid mite (Acari, Mesostigmata) associated with animal and human decomposition. Experimental and Applied Acarology, 61: 415-429. http://dx.doi.org/10.1007/ s10493-013-9710-x

Maslov, A.D. and Matusevich, L. S. 2008. Mites' (Acari) role in the population dynamics of bark beetles (Coleoptera, Scolytidae). Lesnoy Vestnik, 1: 66-72. [In Russian]

Moraes, G.J. de, Britto, E.P.J., Mineiro, J.L. de C., and Halliday, B. 2016. Catalogue of the mite families Ascidae Voigts and Oudemans, Blattisociidae Garman and Melicharidae Hirschmann (Acari: Mesostigmata). Zootaxa, 4112 (1): 1-299. http://dx.doi. org/10.11646/zootaxa.4112.1.1

Moraes, G.J. de, Venancio, R., Santos, V.L.V. dos, and Paschoal, A.D. 2015. Potential of Ascidae, Blat- 
tisociidae and Melicharidae (Acari: Mesostigmata) as biological control agents of pest organisms. In: D. Carrillo, G.J. de Moraes, and J.E. Peña (Eds.). Prospects for Biological Control of Plant Feeding Mites and Other Harmful Organisms. Progress in Biological Control, 19. Springer International Publishing Switzerland, pp. 33-75. http://dx.doi. org/10.1007/978-3-319-15042-0_2

Nikolsky, V.V. 1984. New species of gamasid mites (Parasitiformes, Gamasina) from Siberia. Novye $i$ Maloizvestnye Vidy Fauny Sibiri, 14: 26-33. [In Russian]

OConnor, B.M., Colwell, R.K., and Naeem, S. 1991. Flower mites of Trinidad II. The genus Proctolaelaps (Acari: Ascidae). Great Basin Naturalist, 51: 348-376.

Pernek, M., Hrasovec, B., Matosevic, D., Pilas, I., Kirisits, T., and Moser, J.C. 2008. Phoretic mites of three bark beetles (Pityocteines spp.) on Silver fir. Journal of Pest Science, 81: 35-42. http://dx. doi.org/10.1007/s10340-007-0182-9

Petrova, A.D. 1982. On the fauna of soil dwelling gamasid mites (Parasitiformes; Mesostigmata) of Moscow Province. In: M.S. Ghilyarov (Ed.). Soil Invertebrates of Moscow Province. Nauka, Moscow, pp. 77-84. [In Russian]

Rueda-Ramírez, D., Varela, A., and Moraes, G.J. de. 2016. Soil mites of the families Ascidae, Blattisociidae and Melicharidae (Acari: Mesostigmata) from mountainous areas of Colombia. Zootaxa, 4127 (3): 493-514. http://dx.doi.org/10.11646/ zootaxa.4127.3.5

Rybin, S.N. 1983. Gamasid mites of Chiroptera and their habitats from Southern Kirghizia (Gamasina). Parasitology, 17: 355-360. [In Russian]

Salmane, I. 2001. A check-list of Latvian Gamasina mites (Acari, Mesostigmata) with short notes to their ecology. Latvijas entomologs, 38: $50-61$.

Salmane, I. 2005. Addition to the Latvian Mesostigmata (Acari, Parasitiformes) check-list. Latvijas entomologs, 42: 58-62.

Salmane, I. 2007. New and rare Mesostigmata mites (Acari, Parasitiformes) in Latvia. Latvijas entomologs, 44: 127-128.

Samšiňák, K. 1960. Über einige forstwirtschaftlich wichtige Milben der Gattung Proctolaelaps Berlese 1923. Československá Parasilogie, 7: 297-307.

Schweizer, J. 1949. Die Landmilben des Schweizerischen Nationalparkes. 1. Teil: Parasitiformes Reuter 1909. Ergebnisse der Wissenschaftlichen Untersuchung des Schweizerischen Nationalparks. Neue Folge, 2 (21): 1-99.

Stone, C. 1988. A new species of Proctolaelaps (Acari: Ascidae) from New South Wales, Australia. Acarologia, 29: 319-327.

Treat, A.E., Niederman, L. 1967. Three species of Proctolaelaps (Acarina: Mesostigmata) from noctuid moths. American Museum Novitates, 2312: 1-12.

Vitzthum, H.G. 1923. Acarologische Beobachtungen. 7 Reiche. Archiv für Naturgeschichte, A 89 (2): 97-181.

Westerboer, I. 1963. Die Familie Podocinidae Berlese 1916. Abschnitt IV. In: H.J. Stammer (Ed.). Beiträge zur Systematik und Ökologie mitteleuropäischer Acarina. Band II. Mesostigmata I. Akademische Verlagsgesellschaft Geest and Portig K.-G., Leipzig, pp. 179-450

Wilson, D.S. 1980. The Natural Selection of Populations and Communities. The Benjamin/Cummings Publishing Company, Inc. Menlo Park, California, 186 pp.

Wisniewski, J. 1980. Zwei neue mit Proctolaelaps xyloteri Sams. (Mesostigmata, Blattisociidae) verwandte Proctolaelaps-Arten aus Polen. Acarologia, 21: 3-8. 